Boletín de la Sociedad Geológica Mexicana

VOLUMEN 67, NÚM. 3, 2015, P. 479-491

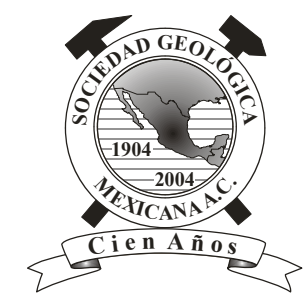

\title{
Identification of diagenetic calcium arsenates using synchrotron-based micro X-ray diffraction
}

\author{
Francisco Castillo ${ }^{1,2,3}$, Miguel Avalos-Borja ${ }^{4,5}$, Heather Jamieson ${ }^{6}$, \\ Gerardo Hernández-Bárcenas ${ }^{1}$, Nadia Martínez-Villegas ${ }^{1, *}$ \\ ${ }^{1}$ IPICyT, Instituto Potosino de Investigación Científica y Tecnológica, División de Geociencias Aplicadas, Camino a la Presa San José \\ No. 2055, Col. Lomas 4a Sec. 78216, San Luis Potosí, SLP, México. \\ ${ }^{2}$ IPICyT, Instituto Potosino de Investigación Científica y Tecnológica, División de Materiales Avanzados, San Luis Potosí, SLP, \\ México. \\ ${ }^{3}$ CONACYT Research Fellow, Instituto de Geología, Universidad Autónoma de San Luis Potosí. \\ ${ }^{4}$ Centro de Nanociencias y Nanotecnología-UNAM, Ensenada, BC, México. \\ ${ }^{5}$ On leave at IPICyT, Instituto Potosino de Investigación Cientifica y Tecnológica, División de Materiales Avanzados, San Luis Potosí, \\ SLP, México. \\ ${ }^{6}$ Department of Geological Engineering, Queen's University, Kingston, ON, Canada. \\ *nadia.martinez@ipicyt.edu.mx
}

\begin{abstract}
In this work, we identify the type of calcium arsenates found in sediment samples from an aquifer located in Matehuala, San Luis Potosí, México. Sediments in contact with levels up to $158 \mathrm{mg} / \mathrm{L}$ of arsenic in neutral $\mathrm{pH}$ water were studied by X-ray diffraction, scanning electron microscopy coupled to energy dispersive X-ray analyses (SEM-EDS), and synchrotron based X-ray diffraction. Identification of these calcium arsenates by X-ray analysis has proved to be very difficult to achieve because the precipitates of interest are on the microscale and immerse in a matrix of calcite, gypsum, and quartz comprising nearly $100 \%$ of the samples. Needle-like specimens composed of calcium, arsenic, and oxygen were, however, commonly observed in sediment samples during SEM-EDS analyses in backscattered mode. Synchrotron based X-ray analyses revealed some peaks that were compared with published data for guerinite, haindingerite, and pharmacolite suggesting that these were the calcium arsenates present in sediments, the calcium arsenates that control the solubility of arsenic in the contaminated aquifer in Matehuala, and the calcium arsenates that prevail in the long-term in the environment after cycles of dissolution and precipitation. The identification of these calcium arsenates is consistent with the environmental conditions prevailing at the study area and the SEM-EDS observations. However, its identification is not unequivocal as the comparison of experimental data collected in single crystal specimens against X-ray diffraction references collected in powders prevents a strictly proper identification of the specimens analyzed. In this way, scorodite was also identified by synchrotron based Xray analyses however its presence is inconsistent with the environmental conditions and the calcium arsenate associations found in this study. Scorodite identification was therefore considered tentative. A thorough examination, with additional and/or improved analytical techniques, should be undertaken to find an environmentally sound explanation for the diffraction peaks assigned to scorodite, which might be from a clay a mineral, probably with no arsenic.
\end{abstract}

Keywords: calcium arsenates, arsenic contamination, guerinite, haindingerite, pharmacolite, diagenetic calcium arsenates.

\section{Resumen}

En este trabajo identificamos el tipo de arseniatos de calcio que se encuentran en muestras de sedimento de un acuifero altamente contaminado con arsénico ubicado en Matehuala, San Luis Potosí, México. Los sedimentos en contacto con hasta 158 mg/L de arsénico 
en agua a pH neutro se estudiaron por difracción convencional de rayos X, microscopía electrónica de barrido acoplado a análisis de dispersión de energía de rayos X (SEM-EDS) y micro difracción de rayos X en sincrotrón. La identificación de arseniatos de calcio por análisis convencionales de difracción de rayos X no fue posible debido a que los especímenes de interés son de tamaño microscópico y se encuentran en una matriz de calcita, yeso y cuarzo que comprende casi el $100 \%$ de las muestras, lo que imposibilita separar la señal de los arseniatos de la señal de la matriz ylo el ruido. No obstante, especímenes aciculares compuestos de calcio, arsénico y oxígeno se observaron comúnmente en las muestras de sedimento durante los analices SEM-EDS utilizando un detector de electrones retrodispersados. En contraste, los análisis de rayos $X$ en sincrotrón permitieron revelar algunos picos característicos de guerinita, haidingerita y farmacolita, lo que sugiere que estos son los arseniatos de calcio presentes en los sedimentos, los arseniatos de calcio que controlan la solubilidad del arsénico en el acuífero contaminado en Matehuala y los arseniatos de calcio que prevalecen a largo plazo en el ambiente después de ciclos de disolución y precipitación. La identificación de estos arseniatos es consistente con las condiciones ambientales del sitio de estudio y las observaciones SEM-EDS, sin embargo, dicha identificación no es inequívoca debido a la comparación de patrones experimentales de difracción de rayos X tomados en monocristales contra tarjetas de difracción de polvos, lo que previene la identificación estrictamente apropiada de los especímenes analizados. En este sentido, también se identificó escorodita pero su presencia es cuestionable a pH 7 y en presencia de guerinita, haidingerita y farmacolita por lo que este último resultado debe tomarse con reserva y un estudio más profundo, con técnicas analíticas adicionales y/o mejoradas, debe llevarse a cabo para encontrarle una explicación ambientalmente consistente a los picos de difracción de rayos X asignados a la escorodita, mismos que podrían corresponder a algún mineral arcilloso que podría no contener arsénico.

Palabras clave: arseniatos de calcio, contaminación con arsénico, guerinita, haidingerita, arseniatos de calcio diagénicos.

\section{Introduction}

In the past, lime neutralization has been used to precipitate arsenic from process solutions as calcium arsenates (Bothe and Brown, 1999a; Robins, 1981; Swash and Monhemius, 1995). Typical precipitates derived from this stabilization technology comprise a range of compounds with variously described stoichiometries, degrees of hydration and solubilities (Bothe and Brown, 1999a, 1999b; Nishimura and Robins, 1998; Zhu et al., 2006) that are further disposed of in soils (Robins, 1981).

An examination of the information available in the literature resulted in 22 calcium arsenates, including several dimorphs and hydrates (Table 1). Although it is not clear whether all arsenates with such stoichiometry indeed do exist (Nordstrom et al., 2014), no calcium arsenate will be suitable for arsenic immobilization unless the $\mathrm{pH}$ remains high in soils and large amounts of calcium are present (Magalhaes and Williams, 2007; Swash and Monhemius, 1995).

In the presence of excess lime, calcium arsenates appear to have low solubility (Table 1) (Bothe and Brown, 1999b; Nordstrom et al., 2014; Swash and Monhemius, 1995; Zhu et al., 2006) but these are expected to dissolve after the $\mathrm{pH}$ buffering effect of the excess lime is reduced through lime solubility and carbonation (Swash and Monhemius, 1995). Arsenic mobilization from calcium arsenates has proved to lead to ultrahigh concentrations of arsenic in surface and groundwater (Martínez-Villegas et al., 2013). Literature indicates, however, a lack of knowledge as to the calcium arsenates that are actually present in the environment controlling arsenic mobilization after long-term disposal.

Calcium hydroxide arsenate hydrates, johnbaumite, and calcium arsenate hydrates (Table 1) are the major phases reported to precipitate during arsenic stabilization using lime followed by guerinite, ferrarisite, pharmacolite, and haindengerite as the calcium/arsenic ratio and $\mathrm{pH}$ decreased (Table 1) (Bothe and Brown, 1999a, 1999b; Nishimura and Robins, 1998; Zhu et al., 2006). Guerinite, ferrarisite, pharmacolite, and haindengerite are therefore the calcium arsenates more likely to prevail in the environment, where soil $\mathrm{pH}$ and aqueous calcium concentrations are usually controlled by equilibrium with less soluble calcium compounds (Magalhaes, 2002). To the best of our knowledge, no study has specifically identified calcium arsenates precipitates after their disposal in soils. Nevertheless, sainfeldite, guerinite, pharmacolite, haindingerite, and weillite have been reported to occur on primary ores containing arsenic or native arsenic in carbonate gangue (Ondrus et al., 1997), mines (Bowell and Parshley, 2005; Pierrot, 1964), industrial sites (Julliot et al., 1999), and laboratory experiments at circumneutral pHs and low calcium/arsenic ratios (Bothe and Brown, 2002, 1999b; Nishimura and Robins, 1998; Pierrot, 1964; Swash and Monhemius, 1995). Unequivocal calcium arsenate identification is challenging in natural (Onac et al., 2007; Ondrus et al., 1997) or impacted environments (Donahue and Hendry, 2003; Pantuzzo and Ciminelli, 2010) due to the presence of (many different) calcium arsenates in samples largely dominated by other major minerals and/ or because the X-ray patterns do not compare closely to published data and, in laboratory experiments, due to lack of reproducible and ambiguous X-ray patterns that do not match any known phases (Bothe and Brown, 1999a, 1999b; Myneni et al., 1997).

The present investigation pertains to an environment 
Table 1. X-ray diffraction "cards" and solubility products available in the literature for calcium arsenates showing lower solubility products for the more alkaline calcium arsenates.

\begin{tabular}{|c|c|c|c|c|}
\hline $\mathrm{Ca} /$ As ratio & Mineral name & Chemical Formula & Card \# & $\log K_{s p}$ \\
\hline \multirow[t]{4}{*}{0.5} & Svenekite & $\mathrm{Ca}\left(\mathrm{H}_{2} \mathrm{AsO}_{4}\right)_{2}$ & $00-051-1466(1)$ & \\
\hline & & & $00-044-0279(2)$ & \\
\hline & & & 01-071-0920 (3) & \\
\hline & & & $04-009-3768$ (4) & \\
\hline \multirow[t]{14}{*}{1.0} & Weilite & $\mathrm{CaHAsO}_{4}$ & $00-016-0710 *(5)$ & $+2.36(28)$ \\
\hline & & & $04-009-6282(6)$ & \\
\hline & Haidingerite & $\mathrm{CaHAsO}_{4} \cdot \mathrm{H}_{2} \mathrm{O}$ & $04-009-3750(7)$ & $-4.79(24)$ \\
\hline & & & & $+3.23 \pm 0.07(27)$ \\
\hline & & & $04-009-9646(8)$ & \\
\hline & & & $00-018-0288^{*}(9)$ & \\
\hline & & & 01-070-1581 (10) & \\
\hline & & & 01-075-0899 (9) & \\
\hline & Pharmacolite & $\mathrm{CaHAsO}_{4} \cdot 2 \mathrm{H}_{2} \mathrm{O}$ & $00-025-0138 *(11)$ & $-4.68(26)$ \\
\hline & & & $04-011-2609(12)$ & \\
\hline & & & $04-011-1576(13)$ & \\
\hline & Calcium Hydrogen Arsenate & $\mathrm{CaHAsO}_{4} \cdot 3 \mathrm{H}_{2} \mathrm{O}$ & 00-023-0870 (14) & \\
\hline & & & $04-009-2415(15)$ & \\
\hline & & & $04-009-6528(16)$ & \\
\hline \multirow[t]{6}{*}{1.25} & Sainfeldite & $\mathrm{Ca}_{5} \mathrm{H}_{2}\left(\mathrm{AsO}_{4}\right)_{4} \cdot 4 \mathrm{H}_{2} \mathrm{O}$ & 04-011-0351 (17) & \\
\hline & Vladimirite & $\mathrm{Ca}_{5} \mathrm{H}_{2}\left(\mathrm{AsO}_{4}\right)_{4} \cdot 5 \mathrm{H}_{2} \mathrm{O}$ & 04-009-1837 (18) & \\
\hline & & & $00-017-0162 *(11)$ & \\
\hline & Ferrarisite & $\mathrm{Ca}_{5} \mathrm{H}_{2}\left(\mathrm{AsO}_{4}\right)_{4} \cdot 9 \mathrm{H}_{2} \mathrm{O}$ & $00-033-0280 *(19)$ & $-31.49(24)$ \\
\hline & Guerinite & $\mathrm{Ca}_{5} \mathrm{H}_{2}\left(\mathrm{AsO}_{4}\right)_{4} \cdot 9 \mathrm{H}_{2} \mathrm{O}$ & $00-026-1055^{*}(11)$ & $-30.69(24)$ \\
\hline & & & 04-012-8661 (20) & \\
\hline \multirow[t]{12}{*}{1.5} & Calcium Arsenate Hydrates & $\mathrm{Ca}_{3}\left(\mathrm{AsO}_{4}\right)_{2} \cdot 2 \mathrm{H}_{2} \mathrm{O}$ & 00-017-0739 (11) & \\
\hline & & $\mathrm{Ca}_{3}\left(\mathrm{AsO}_{4}\right)_{2} \cdot 2.25 \mathrm{H}_{2} \mathrm{O}$ & & $-21.40(25)$ \\
\hline & & $\mathrm{Ca}_{3}\left(\mathrm{AsO}_{4}\right)_{2} \cdot 3 \mathrm{H}_{2} \mathrm{O}$ & & $-21.14(25)$ \\
\hline & & $\mathrm{Ca}_{3}\left(\mathrm{AsO}_{4}\right)_{2} \cdot 3.67 \mathrm{H}_{2} \mathrm{O}$ & & $-21.00(24)$ \\
\hline & & $\mathrm{Ca}_{3}\left(\mathrm{AsO}_{4}\right)_{2} \cdot 4 \mathrm{H}_{2} \mathrm{O}$ & 00-017-0441 (11) & $+5.58 \pm 0.40(27)$ \\
\hline & & $\mathrm{Ca}_{3}\left(\mathrm{AsO}_{4}\right)_{2} \cdot 4.25 \mathrm{H}_{2} \mathrm{O}$ & & $-21.00(24)$ \\
\hline & & $\mathrm{Ca}_{3}\left(\mathrm{AsO}_{4}\right)_{2} \cdot 6 \mathrm{H}_{2} \mathrm{O}$ & & \\
\hline & & $\mathrm{Ca}_{3}\left(\mathrm{AsO}_{4}\right)_{2} \cdot 8 \mathrm{H}_{2} \mathrm{O}$ & $00-017-0738(11)$ & \\
\hline & Rauenthalite & $\mathrm{Ca}_{3}\left(\mathrm{AsO}_{4}\right)_{2} \cdot 10 \mathrm{H}_{2} \mathrm{O}$ & $00-035-0569 *(19)$ & \\
\hline & & & 01-076-1636 (21) & \\
\hline & Phaunouxite & $\mathrm{Ca}_{3}\left(\mathrm{AsO}_{4}\right)_{2} \cdot 11 \mathrm{H}_{2} \mathrm{O}$ & $00-041-0581 *(19)$ & \\
\hline & & & 01-076-1635 (21) & \\
\hline \multirow[t]{3}{*}{1.6} & Johnbaumite & $\mathrm{Ca}_{5}\left(\mathrm{AsO}_{4}\right)_{3}(\mathrm{OH})$ & $00-033-0265^{*}(22)$ & $-38.04(24)$ \\
\hline & & & & $-40.12(25)$ \\
\hline & Calcium Hydroxide Arsenate Hydrate & $\mathrm{Ca}_{5}\left(\mathrm{AsO}_{4}\right)_{3} \mathrm{OH} \cdot \mathrm{xH}_{2} \mathrm{O}$ & 00-026-0296 (23) & \\
\hline \multirow[t]{3}{*}{2.0} & Calcium Hydroxide Arsenate Hydrate & $\mathrm{Ca}_{4}(\mathrm{OH})_{2}\left(\mathrm{AsO}_{4}\right)_{2} \cdot 4 \mathrm{H}_{2} \mathrm{O}$ & 00-018-0289 (11) & $-29.20(24)$ \\
\hline & & & & $-27.49(25)$ \\
\hline & & $\mathrm{Ca}_{2}\left(\mathrm{AsO}_{4}\right)(\mathrm{OH}) \cdot 2 \mathrm{H}_{2} \mathrm{O}$ & & $+1.29 \pm 0.68(27)$ \\
\hline
\end{tabular}

"Natural calcium arsenates. (1) Ondrus et al. (1997), (2) Worzala (1993), (3) Chiari and Ferraris (1971), (4) Ferraris and Jones (1972), (5) Herpin (1963), (6) Ferraris and Chiari (1970), (7) Ferraris et al. (1972a), (8) Binas (1966), (9) Cassien and Herpin (1966), (10) Calleri and Ferraris (1967), (11) Pierrot (1964), (12) Ferraris (1969), (13) Ferraris et al. (1971), (14) Brasse (1970), (15) Catti and Ferraris (1973), (16) Ferraris et al. (1972b), (17) Ferraris and Abbona (1972), (18) Catti and Ivaldi (1981), (19) Bari (1980), (20) Catti and Ferraris (1974), (21) Bari (1982), (22) Catti and Ivaldi (1983), (23) Dunn et al. (1980), (24) Bothe and Brown (1999), (25) Zhu et al. (2006), (26) Rodríguez-Blanco et al. (2007), (27) Nishimura and Robins (1998), (28) Mahapatra et al. (1986). 
contaminated with calcium arsenates collected in a demolished smelter located in Matehuala, San Luis Potosi, Mexico (Figure 1), which originated from the stabilization of arsenic in metallurgical effluents with lime. In this study, we determine the identity of diagenetic calcium arsenates collected in sediments of the contaminated aquifer. Given the difficulties encountered in the identification of these calcium arsenates immersed in a matrix largely comprised of other calcium rich phases, such as calcite and gypsum, we describe in detailed the different approaches used in this study.

\section{Materials and methods}

2.1. Mineralogy and total arsenic, calcium and iron analyses in sediment samples

Sediment samples contaminated with calcium arsenates were collected in a spring grossly polluted with arsenic. The spring is located in the vicinity of an abandoned smelter where residues of calcium arsenates from a former process of arsenic stabilization using lime took place six decades ago (Martínez-Villegas et al., 2013). The abandoned smelter and the spring are located in Matehuala, an urban center in San Luis Potosi, Mexico (Figure 1) where the longterm disposal of calcium arsenates has led to cycles of dissolution and precipitation of soluble calcium arsenates that cause ultrahigh concentrations of arsenic in surface and groundwater (Martínez-Villegas et al., 2013). Ultrahigh concentrations of arsenic in the spring vary from 36 to $158 \mathrm{mg} / \mathrm{L}$ in the water overlying the sediments (MartínezVillegas et al., 2013). The spring is found within a perched aquifer that runs in a $\mathrm{W}$ to $\mathrm{E}$ direction and is believed not to mix with a low-As shallow aquifer $(<21 \mu \mathrm{gAs} / \mathrm{L})$ that runs NW to SE between 15 and $50 \mathrm{~m}$ in depth (MartínezVillegas et al., 2013). Procedures used in the sampling and determination of arsenic in the overlying water are described in detail in Martínez-Villegas et al. (2013). Briefly, water samples were collected over a year on a monthly basis at the spring in $120 \mathrm{~mL}$ polypropylene bottles previously washed with $10 \% \mathrm{HNO}_{3}$ and rinsed with deionized water. Water samples were filtered through a $0.45 \mu \mathrm{m}$-pore membrane, acidified to $\mathrm{pH}<2$, and stored at $4{ }^{\circ} \mathrm{C}$ until analysis. Total dissolved arsenic was determined by inductively coupled plasma mass spectroscopy (ICP-MS).

Sediment samples were collected using a shovel within the first $0-5 \mathrm{~cm}$ of depth. Sediments were stored in

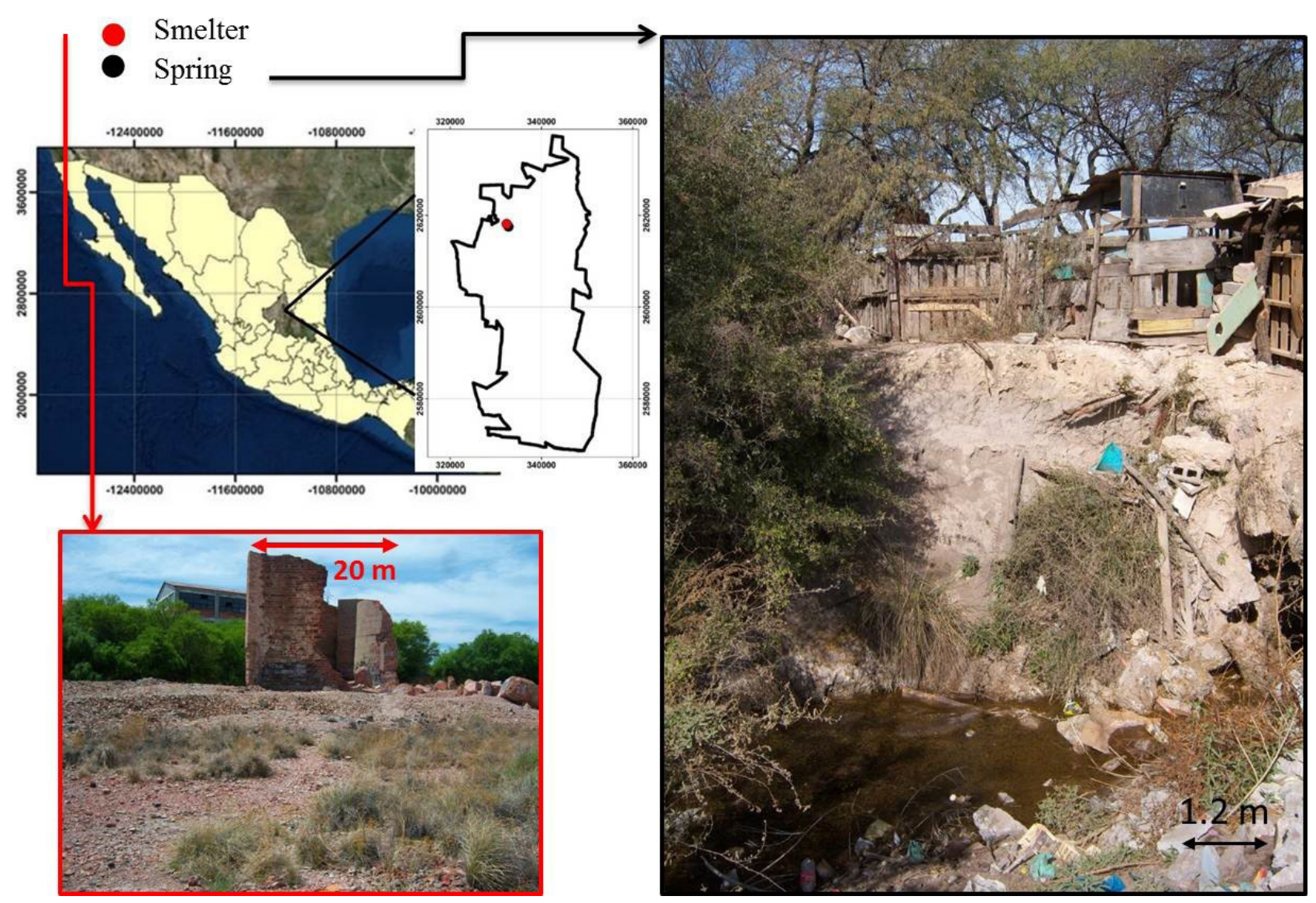

Figure 1. Location and pictures of the demolished smelter (332383"W, 2618114"N) and the arsenic contaminated spring (332802"W, 2617518"N) located in Matehuala, San Luis Potosi, Mexico. 
polyethylene bags and maintained at $4{ }^{\circ} \mathrm{C}$ until air-dried, ground and homogenized. Bulk mineralogy was determined by X-ray diffraction (XRD) in sediment samples using a Bruker D8 ADVANCE X-ray diffractometer fitted with a $\mathrm{Cu} \mathrm{K} \alpha$ source. Sediment samples for X-ray powder diffraction were compacted into a glass holder covering an area of $1.5 \mathrm{~cm}^{2}$ and analyzed from $5^{\circ}$ to $90^{\circ} 2 \theta$ with a step interval of $0.012 \theta$ and a counting time of $4 \mathrm{~s}$ per step. Phase identification was made by matching the experimental diffractogram with data from PDF4 of the ICDD (International Center of Diffraction Data). Total arsenic, calcium, and iron were determined by inductively coupled plasma optical emission spectroscopy (ICP-EOS) in digests of sediment samples. For the digestion of samples, a representative $0.1 \mathrm{~g}$ sample was digested with $10 \mathrm{~mL}$ of aqua regia $\left(\mathrm{HNO}_{3} / \mathrm{HCl}\right.$ 3:2 $\left.\mathrm{V} / \mathrm{V}\right)$ in an Ethos 1 advanced microwave digestion system for $10 \mathrm{~min}$ at $150{ }^{\circ} \mathrm{C}$ using a $750 \mathrm{~W}$ lamp with a ramp heating of $10 \mathrm{~min}$ and a ramp cooling of $30 \mathrm{~min}$. For ICP analyses, the resultant digests were filtered through a $0.45 \mu \mathrm{m}$ membrane, and then diluted to a final volume of $25 \mathrm{~mL}$.

\subsection{Methods initially used to identify calcium arsenates}

As mentioned previously, calcium arsenate identification is challenging. Attempts include conventional X-ray analyses, imaging and elemental analyses by SEM-EDS, and sample preparation in a Helios NanoLab for electron diffraction analyses in transmission electron microscopy (TEM). Small amounts of sediment samples were directly mounted on a carbon tape. Each carbon tape was fixed on an aluminum holder. Scanning electron microscope (SEM) analyses in sediment samples were done in a FEI Quanta 200 SEM coupled to an EDAX energy dispersive system. SEM analyses were performed using either a large field or a backscattered electron detector at low vacuum $(10-130$ $\mathrm{kPa}$ ). Additionally, sample manipulations were performed in a Helios NanoLab Dual Beam 600 to try to extract calcium arsenates specimens from sediment samples for milling until producing suitable quality samples for TEM imaging and diffraction analyses.

\subsection{Micro X-ray diffraction analyses}

Liftable thin sections of calcium arsenate contaminated sediment samples were prepared to identify selected targets of calcium arsenates by synchrotron microanalysis using petrographic techniques (Walker et al., 2009). Sections were first prepared on pure silica glass slides and then explored by SEM-EDS to identify those regions with specimens of interest. Sections where calcium arsenates were found were removed from the glass slide by soaking the slide in acetone and lifting it on kapton tape to be then analyzed at Beamline X26A at the National Synchrotron Light Source at Brookhaven National Laboratory, New York. Beamline X26A has proved to be suitable for obtaining high-resolution microdiffraction data on very small $(5 \mu \mathrm{m})$ crystals (Jamieson et al., 2011; Walker et al., 2009). Once mounted on the X26-A beamline, liftable thin sections were explored by optical microscopy to identify those regions of interest. A detailed elemental map was obtained to identify spots with high levels of arsenic, calcium, and iron. Micro $\mathrm{X}$-ray diffraction was completed in transmission mode using a Rayonix SX-165 CCD Image Plate area detector. The incident X-ray beam was tuned to a wavelength of $0.7093 \AA$, and the distance from the sample detector was $247 \mathrm{~mm}$. Calibration of the detector was done using the SRM674a diffraction standard $\alpha-\mathrm{Al}_{2} \mathrm{O}_{3}$ and Ag-Behenate $\left(\mathrm{AgC}_{22} \mathrm{H}_{43} \mathrm{O}_{2}\right)$. 2-D X-ray patterns were recorded on selected spots. Calibrations and corrections for detector distortions (camera sample distance, the camera tilt and rotation, and the beam center on the camera plane) were done using Fit2D ${ }^{\mathrm{TM}}$ software (Hammersley, 1998). One dimensional $\mathrm{X}$-ray patterns were obtained and matched with those compiled in the PDF4 database of the ICDD. Calcium arsenates in the database are shown in Table 1. A total of 15 target spots were analyzed within three different liftable thin sections (Table 2).

\section{Results}

3.1. Mineralogy and total arsenic, calcium, and iron concentrations in sediment samples

According to peak matching with simulated data from the PDF4 of the ICDD, conventional X-ray diffraction analyses consistently show sediments comprise gypsum, calcite, and quartz (Figure 2). Total arsenic concentrations in sediment

Table 2. Arsenic, calcium, and iron counts from X-ray fluorescence analyses at each target spot selected for X-ray diffraction analyses.

\begin{tabular}{clccc}
\hline Sample & Target spot & As & Ca & Fe \\
\hline \multirow{4}{*}{ A } & TS_01A_44_67 & 4526 & 801 & 789 \\
& TS_01A_44_68 & 3261 & 940 & 810 \\
& TS_01A_44_69 & 2361 & 705 & 1051 \\
& TS_01B_27_91 & 3649 & 1047 & 1297 \\
& TS_01B_27_92 & 2067 & 1062 & 1010 \\
& TS_01B_27_93 & 115 & 1077 & 4707 \\
B & TS_01B_27_94 & 89 & 1021 & 5605 \\
& TS_01B_27_95 & 51 & 3059 & 936 \\
& TS_01B_27_96 & 29 & 6007 & 316 \\
& TS_01D_06_58 & 1053 & 1392 & 4038 \\
& TS_01D_06_60 & 570 & 1311 & 1372 \\
& TS_01D_06_61 & 396 & 1722 & 1079 \\
& TS_01D_06_62 & 68 & 918 & 4270 \\
& TS_01D_06_64 & 61 & 878 & 2626 \\
& TS_01D_06_65 & 112 & 1801 & 1276 \\
\hline
\end{tabular}


samples varied from $261 \mathrm{mg} / \mathrm{kg}$ to $1753 \mathrm{mg} / \mathrm{kg}$ without a clear trend with the concentration of arsenic in the overlying water (Figure 3). Total arsenic concentrations in sediment samples are due to a process of diagenetic precipitation of calcium arsenates firstly dissolved upstream in the terrains of a currently demolished smelter (Martínez-Villegas et al., 2013). In the case of calcium, total calcium concentrations vary from $8.7 \%$ to $10.2 \%$ and might rather be controlled by calcite and gypsum. Due to the commanding role of iron in the regulation of arsenic mobility in the environment, we also measured total iron concentrations in sediment samples. Total iron concentrations vary from $1.1 \%$ to $1.3 \%$, however no correlation has been observed between arsenic and iron in this study area (Martínez-Villegas et al., 2013).
3.2. Failed methods used to attempt to identify calcium arsenates

Factors complicating calcium arsenate identification in calcareous sediments include the relatively low concentration of the minerals of interest as compared with bulk sample, sample heterogeneity, sample composition, and sample properties.

The relatively low concentration of calcium arsenates in bulk samples hinders calcium arsenate data in X-ray diffraction analyses and makes impossible its identification. In this study, no calcium arsenates were possible to identify by conventional X-ray analysis in sediment samples (Figure 2 ). These results were consistent with previous studies that had failed to identify calcium arsenates using conventional

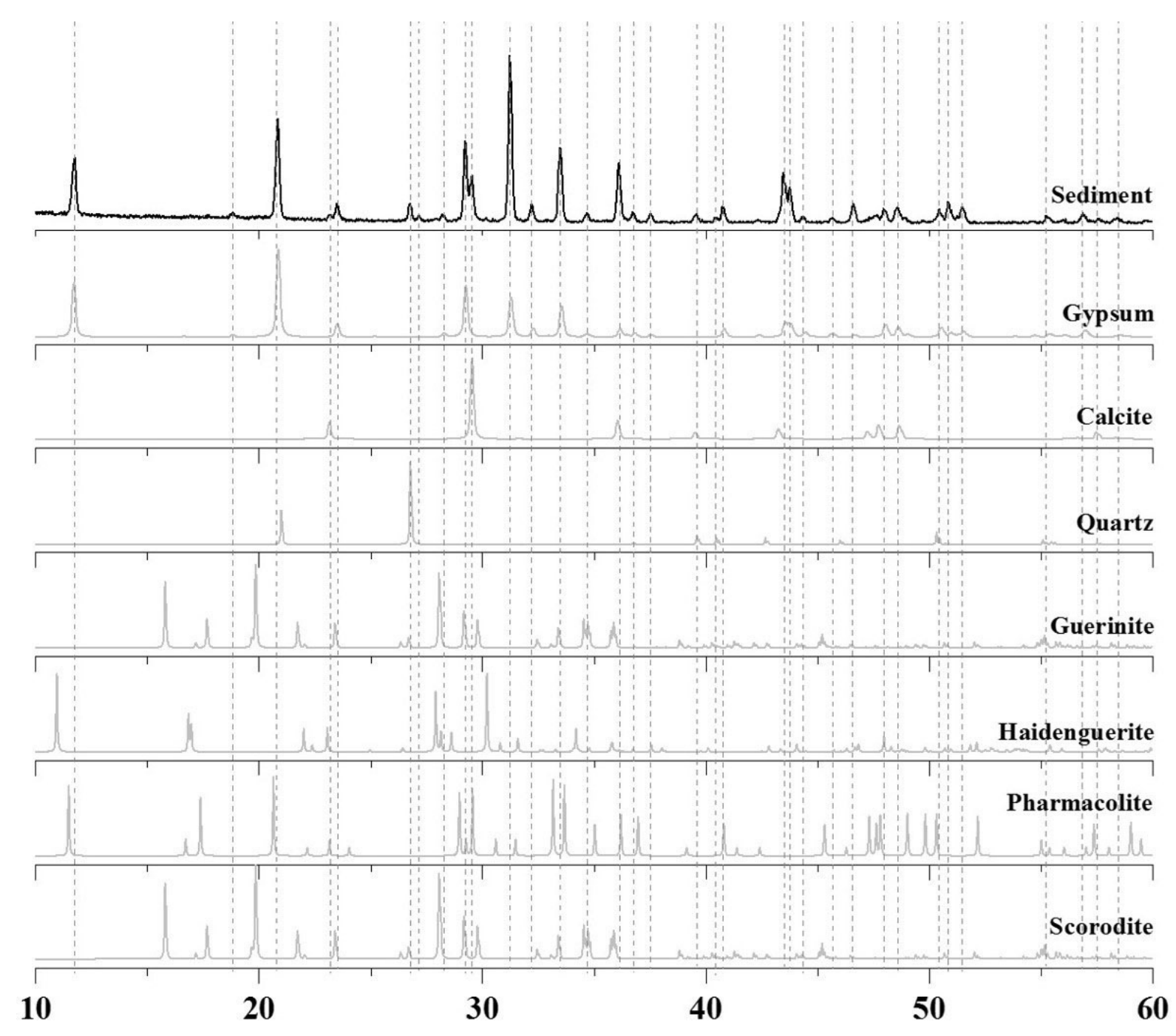

$2 \theta$

Figure 2. X-ray diffractograms representative of sediments in the study area showing how experimental peaks match with simulated gypsum, calcite, and quartz; which is not the case for guerinite, haidinguerite, pharmacolite, and scorodite. According to PDF4 of the ICDD database. 


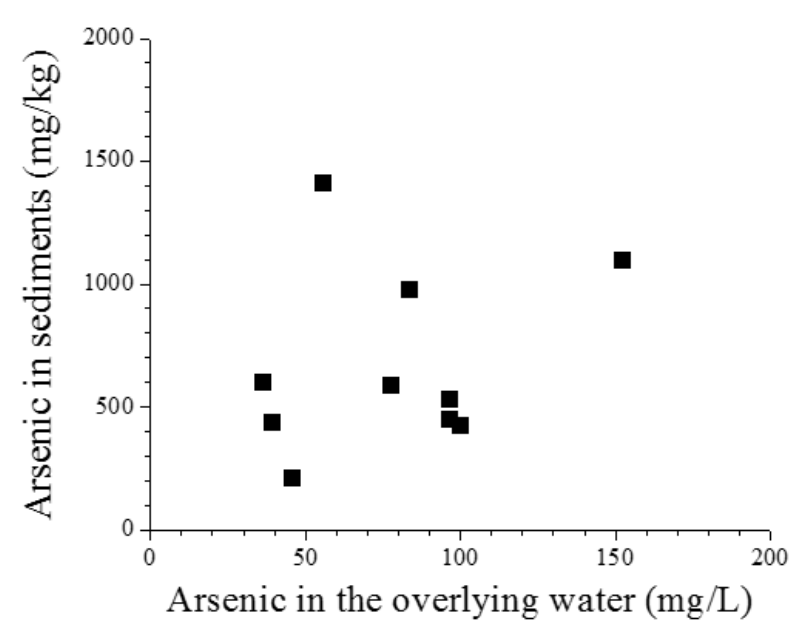

Figure 3. Arsenic concentration in sediments and the overlying water. Arsenic data in the overlying water was taken from Martínez-Villegas, et al. (2013).
X-ray diffraction analysis even in highly contaminated soils containing up to $5 \%$ of arsenic on a mass basis (MartínezVillegas et al., 2013).

On the other hand, the heterogeneous nature of sediment samples greatly complicates their analyses by SEM-EDS. Despite clear evidences of the presence of calcium arsenates in contaminated sediment samples (Figures 4 and 5), we were unable to confirm their presence using chemical spot analyses. This could be due to the small particle size of the arsenates and the "pear" effect of the analytical technique, where both the particle and the matrix are sampled simultaneously. Composition analyses were besides highly deterred by the nonconducting nature of the samples. Image distortions or severe cases of charging during secondary electron SEM analyses, observed as bright regions surrounded by dark haloes (Figure 4a), made difficult to acquire good quality images and therefore good quality
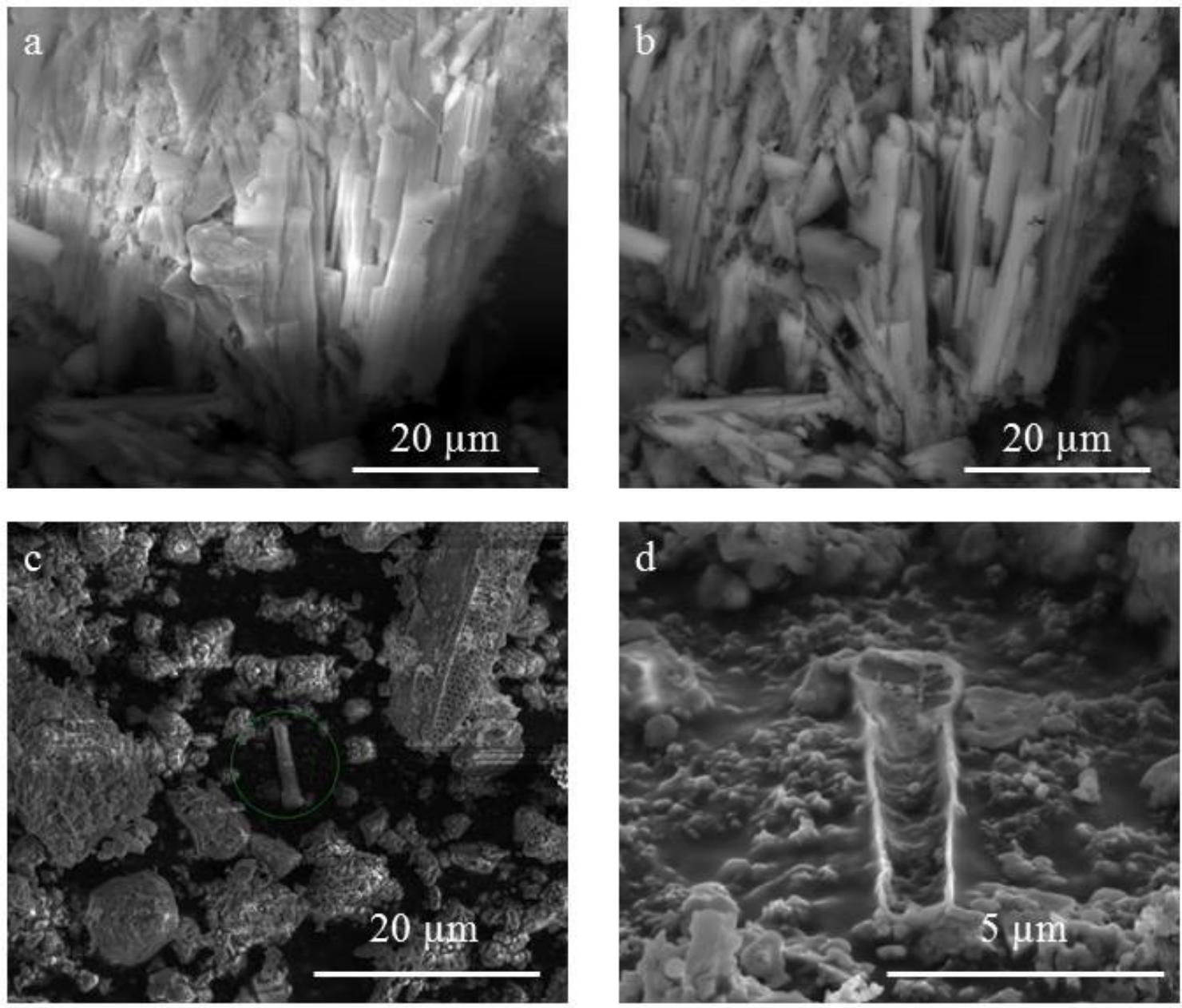

Figure 4. Image distortion, specimen charging, and sample instability problems during SEM observations. (a) Image distortion and calcium arsenate charging occurring during SEM analyses using a large field detector (LFD) of secondary electrons in low vacuum (10 - $130 \mathrm{kPa})$ in a FEI Quanta 200 SEM. (b) Image distortion and charging were usually overcome using a backscattered electron detector (BSD) at expenses of resolution but producing atomic number contrast. The use of a BSD was key to help localize calcium arsenate specimens by contrast in gypsum rich samples. (c) Calcium arsenate specimen found in sediment samples using a Helios NanoLab. (d) Track of the calcium arsenate shown in (c) after sublimation during Helios NanoLab manipulations. 
chemical information results. Calcium arsenates in Figure $4 \mathrm{~b}$ were obtained using a backscattered electron detector, which is less affected by electric charge but with less image resolution, making significantly more difficult to analyze smaller specimens like the diagenetic calcium arsenates present in sediment samples (Figure 5). The disadvantages of sample heterogeneity could have been overcome, in part, and in theory, by preparing ultrathin samples for electron diffraction analyses after TEM, however calcium arsenate specimens were unstable under the Helios NanoLab and no
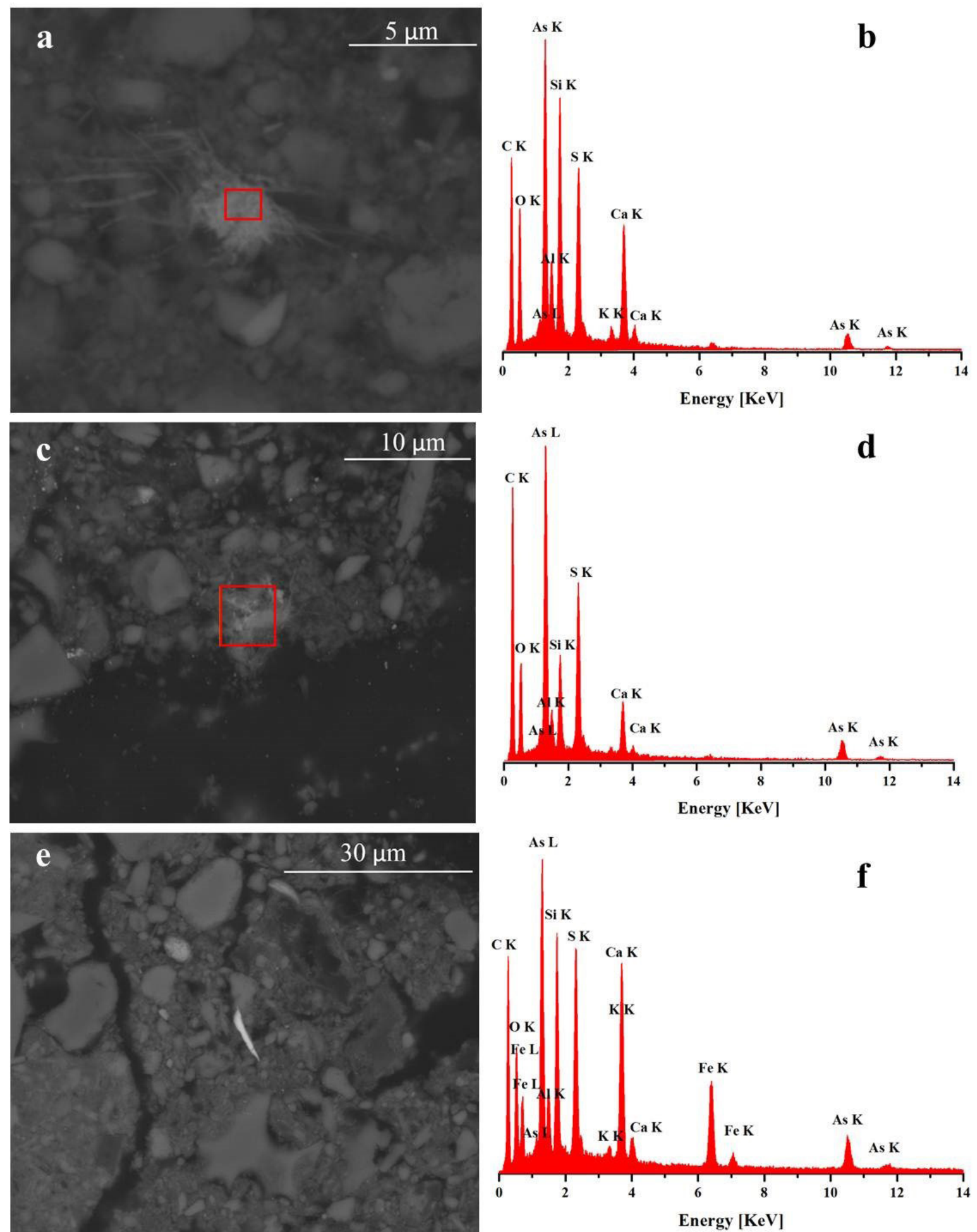

Figure 5. Backscattered SEM images of samples A ( $a$ and b) , B (c and d) and D (e and f) showing diagenetic needle-like minerals commonly found in sediments of the contaminated spring (brighter areas indicate zones of higher atomic number). 
specimens could have ever been extracted for milling and TEM analyses (Figure 4c and d).

\subsection{Micro X-ray diffraction results}

Figure 5 shows SEM images of specimens of calcium arsenates found on silica glass slides and their corresponding EDS analyses. As can be observed, all specimens show a needle-like morphology where EDS analyses revealed the presence of arsenic, calcium, oxygen, carbon, aluminum, silica, sulfur, potassium and iron (Figures 5 a to f) likely due to the presence of calcium arsenates, calcite, gypsum, and quartz. Aluminum and potassium might derive from phyllosilicate clays. Element counts detected by X-ray fluorescence collected in areas where calcium arsenates were observed are shown in Table 2. 2D diffraction patterns collected at each specific target spot were transformed to 1D.

Figure 6 shows the micro-X-ray diffractogram for sample A as compared with data from the PDF4 of the ICDD for gypsum, calcite, quartz, guerinite, haindingerite, pharmacolite, and scorodite. As it can be observed, a large set of peaks showed at positions $2.9,9.1,10.6,12.2,12.7$, $13.4,14.4,15.8,16.3,17.8,19.5,21.4,21.8,22.5,25.5$ and 27.2. Because of the acquisition of data at a micron scale of very specific specimens (Figure 5), it was completely unexpected to observe that calcite, gypsum, and quartz from
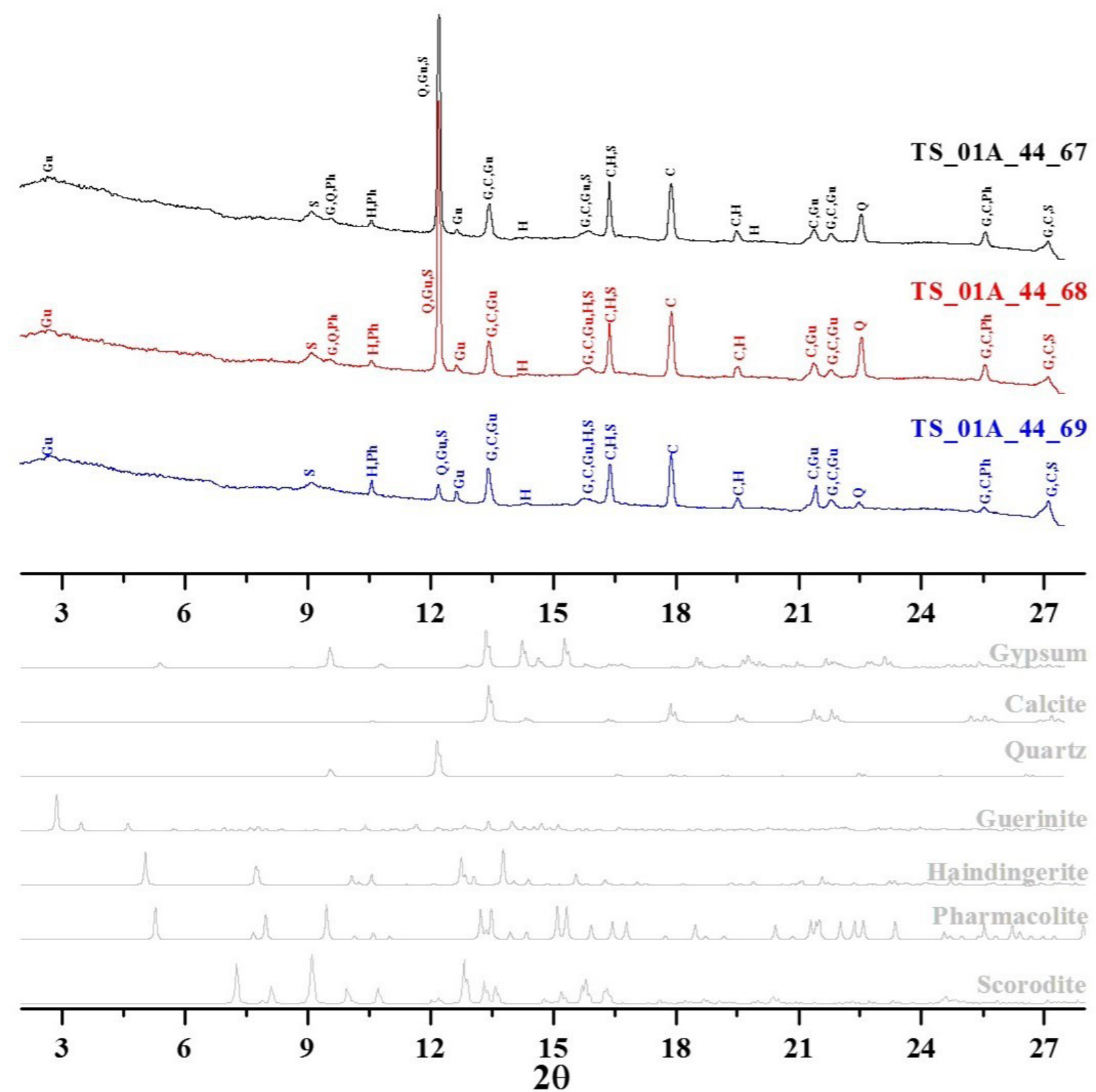

Figure 6. X-ray diffractograms of sample A revealing experimental peaks that match with simulated guerinite, haindingerite, pharmacolite, scorodite, gypsum, calcite, and quartz according to PDF4 of the ICDD database. 
the sediment matrix were still dominant in the diffraction patterns (Figures 6). Peak positions accounting for calcite, gypsum, and quartz were found at 12.2, 12.7, 13.4, 14.4, $15.8,17.8,19.5,21.4,21.8,22.5,25.5$ and 27.2. Remaining peaks (at positions 2.9, 9.1, 10.6 and 16.3) were explained by the presence of guerinite, haindingerite, pharmacolite, and scorodite (Figure 6) that show peaks at these specific positions as well as some other peaks that overlap with the matrix and other calcium arsenates (Figure 6). For example, the peak found at position 2.9, was explained by guerinite, whose reference data show another peak at 13.4 that overlaps with calcite, gypsum, and pharmacolite (Figure 6). Peak overlap was a major limiting factor on the identification of calcium arsenates in this study. Another factor that greatly deterred the identification of calcium arsenates was the collection of single crystal diffraction data as determined by micro-X ray results. Different to X-ray powder measurements, where the random orientation of crystals allows for peak acquisition at every characteristic position with proportional intensities, in single crystal measurements peak acquisition and their relative intensities depend on the orientation of the crystal analyzed. That is, in a single crystal diffractogram, not all the characteristic peaks of the mineral may show up and the intensities might not correspond to those of powder references. In this study, only a few crystal orientations might have diffracted, obtaining therefore incomplete sets of peaks with non-proportional intensities. These complications were observed even for dominant matrix minerals such as gypsum, for which not a whole set of peaks of proportional intensities was obtained (Figure 6). Guerinite, haindingerite, pharmacolite, and scorodite were consistently identified in the rest of the targets analyzed using synchrotron based X ray analyses (Figures 7 and 8). The presence of guerinite, haindingerite, and pharmacolite

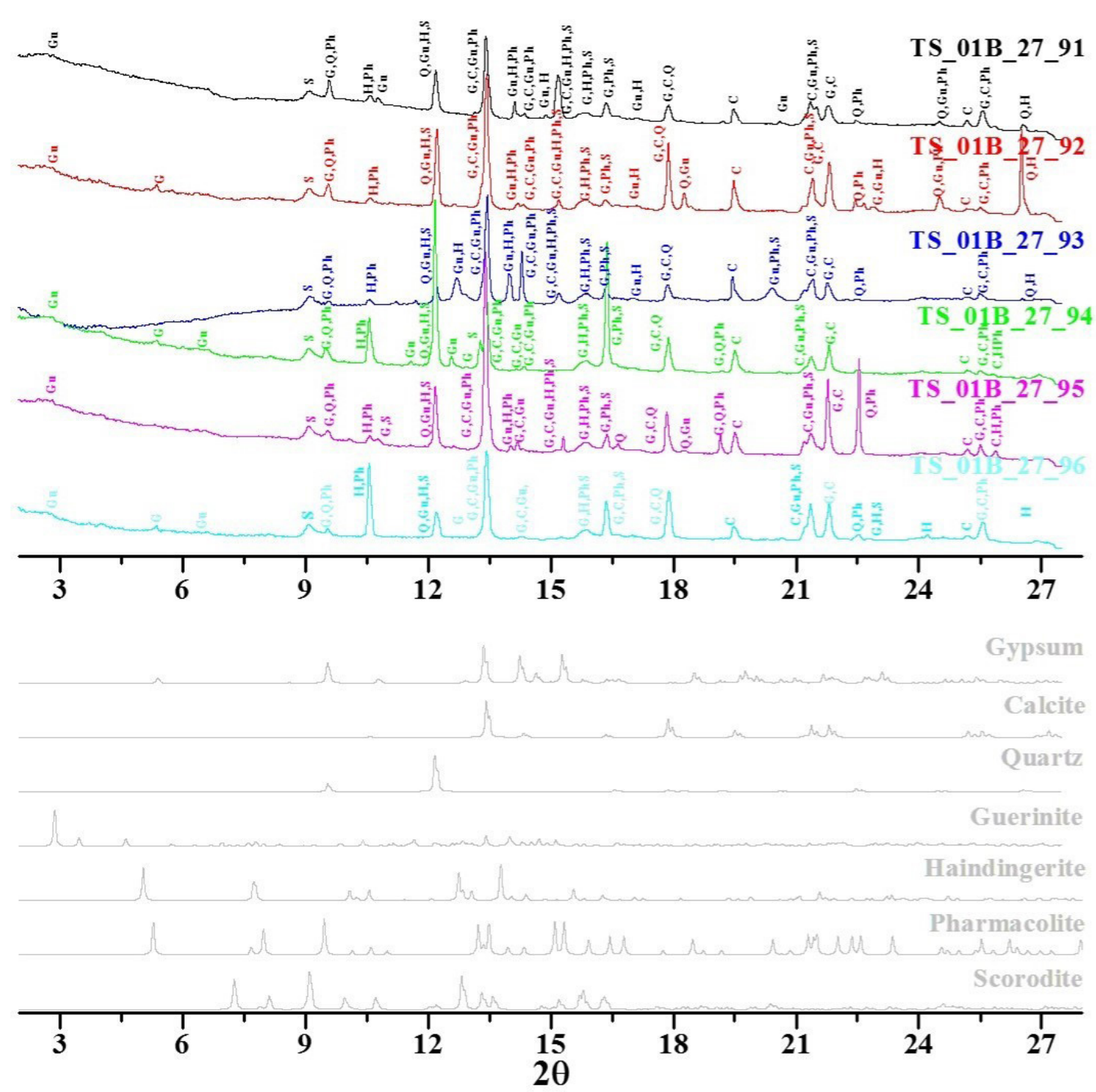

Figure 7. X-ray diffractograms of sample B revealing experimental peaks that match with simulated guerinite, haindingerite, pharmacolite, scorodite, gypsum, calcite, and quartz according to PDF4 of the ICDD database. 


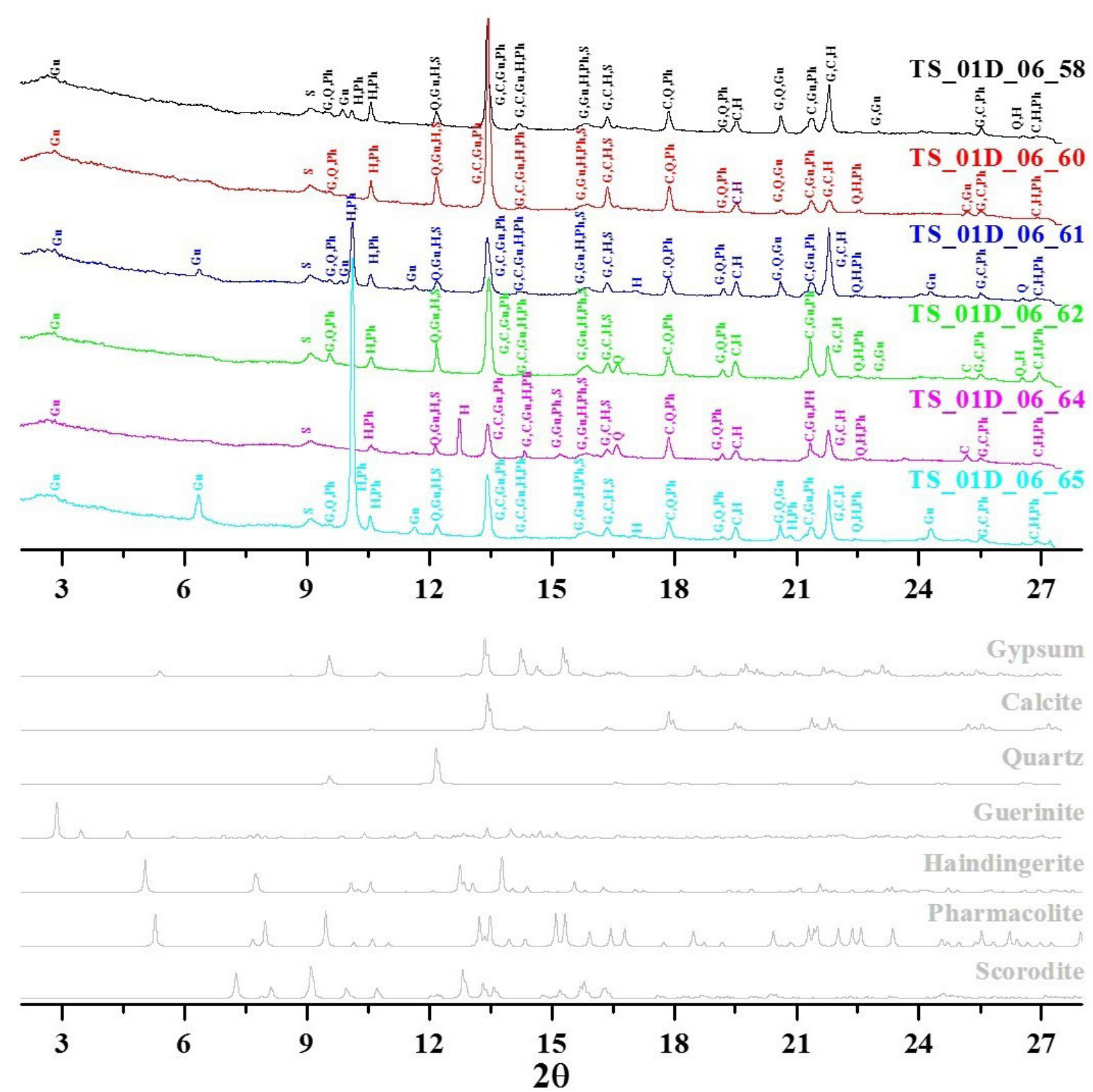

Figure 8. X-ray diffractograms of sample D revealing experimental peaks that match with simulated guerinite, haindingerite, pharmacolite, scorodite, gypsum, calcite, and quartz according to PDF4 of the ICDD database.

as secondary calcium arsenates has been reported to occur at circumneutral, calcium rich environments (Julliot et al., 1999) and in near neutral pH laboratory experiments in the presence of calcium (Bothe and Brown, 1999a, 1999b). In this study, the identification of guerinite and pharmacolite is thermodynamically consistent with data from the water overlying the sediments (Figure 9). While this data does not overlap with the equilibrium of haindingerite, the presence of this phase can be explained by the close association of this mineral with the precipitation of guerinite (Bothe and Brown, 1999a, 1999b; Julliot et al., 1999). On the other hand, the identification of scorodite is inconsistent with the environmental conditions referred in this paper (circumneutral, calcium rich environments) and very unlikely to occur in association with guerinite, haindingerite, and pharmacolite (Figure 9). Furthermore, no additional microscopic, spectroscopy, and/or hydrogeochemical evidences have been observed for the presence of scorodite in the study area therefore a thorough examination, with additional and/or improved analytical techniques, should be undertaken to find an environmentally sound explanation to the diffraction peaks assigned to scorodite, which might be from a clay mineral, probably with no arsenic.

\section{Conclusions}

In this study, guerinite, haindingerite, and pharmacolite were identified in contaminated sediment samples as determined by X-ray synchrotron diffraction that revealed 


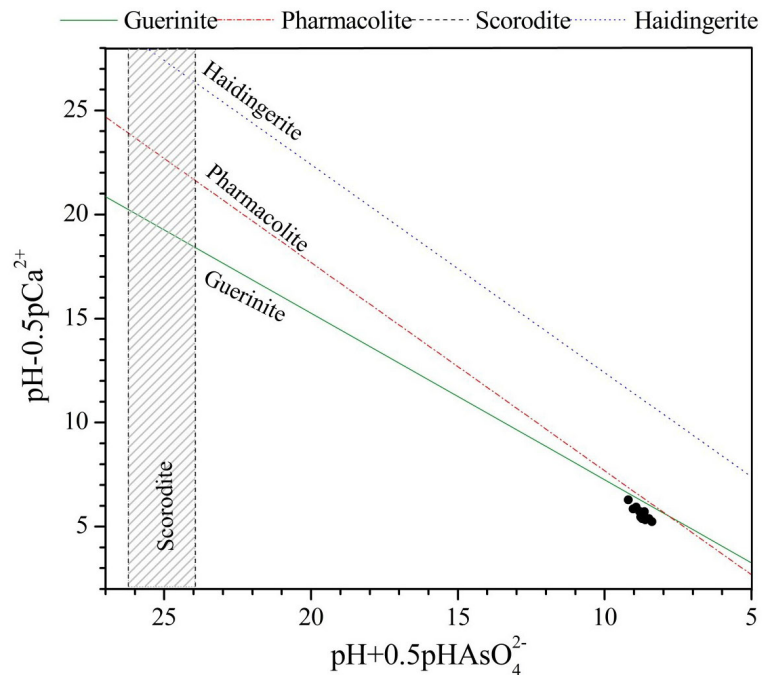

Figure 9. Activity ratio diagram illustrating the data of the water overlying the studied sediments (black dots) is reasonably consistent with the equilibriums of guerinite and pharmacolite but inconsistent with formation of scorodite. The range denoted by the hatched region is where arsenic would be controlled by scorodite dissolution at the spring conditions. Data for this figure was taken from Martínez-Villegas et al. (2013). Guerinite, pharmacolite, and haindingerite equilibriums correspond to the solubility products shown in Table 1.

some peak positions that compared with these minerals. Guerinite, haindingerite, and pharmacolite are diagenetic calcium arsenates present in the aquifer after long-term disposal on soils of (other) original calcium arsenates upstream. Guerinite, haindingerite, pharmacolite are calcium arsenates highly soluble (Table 1). Results from this paper are in agreement with those of our previous paper (Martínez-Villegas et al., 2013) in that calcium arsenates would explain the ultrahigh concentrations of arsenic found in the aquifer. Our current results, however, differ from our previous paper in that we first observed that none of these minerals explained arsenic contamination according to geochemical calculations using PHREEQC (MartínezVillegas et al., 2013). In that case, arsenic contamination was explained by calcium arsenate that showed the same stoichiometry than guerinite but a different solubility product. The challenge today is to match solubility data in the aquifer with their corresponding precipitating phases. In order to do so, an evaluation of the internal consistency of thermodynamic data on calcium arsenates and improved approaches for calcium arsenate identification are needed.

\section{Acknowledgements}

This study was supported by grants CB-2012-183025 and IPICYT S-2694 funded by CONACyT and CursoTaller de Calidad del Agua y Modelación Hidrogeoquímica, respectively. Synchrotron-based X-ray diffractions were collected at beamline X-26A, National Synchrotron Light Source (NSLS), Brookhaven National Laboratory.
X26A is supported by the Department of Energy (DOE) Geosciences (DE-FG02-92ER14244 to The University of Chicago - CARS). Use of the NSLS was supported by DOE under Contract No. DE-AC02-98CH10886. F. Castillo and G. Hernández-Barcenas thank CONACyT for postdoctoral and undergrad fellowships, respectively. Special thanks are due to Gladis Labrada, Beatriz Adriana Rivera Escoto and Ana Iris Peña Maldonado from LINAN-IPICyT, Tyler Nash from Queen's University, and Sue Wirick from University of Chicago.

\section{References}

Bari, $\mathrm{H} ., 1980$, Ferrarisite $\mathrm{Ca}_{5} \mathrm{H}_{2}\left(\mathrm{AsO}_{4}\right) 9 \mathrm{H}_{2}$ a new mineral dimorphous with guerinite: Bulletin de la Société Francaise de Minéralogie et de Cristallographie, 103, 533-540.

Bari, H., 1982, Phaunouxite $\mathrm{Ca}_{3}\left(\mathrm{AsO}_{4}\right)_{2} \cdot 11 \mathrm{H}_{2} \mathrm{O}$ a new mineral strictly associated with Rauenthalite: Bulletin de Minéralogie, 105, 327-332.

Binas, H.Z., 1966, Die Struktur des Haidingerits $\mathrm{CaHAsO}_{4} \cdot \mathrm{H}_{2} \mathrm{O}$ : Zeitschrift für anorganische und allgemeine Chemie, 347, 133.

Bothe, J.V., Brown, P.W., 1999a, Arsenic immobilization by calcium arsenate formation: Environmental Science \& Technolog, 33, 3806-3811.

Bothe, J.V., Brown, P.W., 1999b, The stabilities of calcium arsenates at $23+/-1{ }^{\circ} \mathrm{C}$ : Journal of Hazardous Materials, 69, 197-207.

Bothe, J.V., Brown, P.W., 2002, $\mathrm{CaO}-\mathrm{As}_{2} \mathrm{O}_{5}-\mathrm{H}_{2} \mathrm{O}$ system at $23^{\circ}+/-1{ }^{\circ} \mathrm{C}$ : Journal of the American Ceramic Society, 85, 221-224.

Bowell, R.J., Parshley, J.V., 2005, Control of pit-lake water chemistry by secondary minerals, Summer Camp Pits, Getchell mine, Nevada: Chemical Geology, 215, 373-385.

Brasse, R., 1970, Les orthoarseniates bicalciques et le system Ca- $\mathrm{As}_{2} \mathrm{O}_{5}-$ $\mathrm{H}_{2} \mathrm{O} 20^{\circ} \mathrm{C}$ : Bulletin de la Société Francaise de Minéralogie et de Cristallographie, 2069-2072.

Calleri, M., Ferraris, G., 1967, Struttura della Haidingerite: $\mathrm{CaH}\left(\mathrm{AsO}_{4}\right)$ $\mathrm{H}_{2} \mathrm{O}$ : Periodico di Minerogia, 36, 1 .

Cassien, M., Herpin, P., 1966, Structure cristalline de la haindingerite: Bulletin de la Société Francaise de Minéralogie et de Cristallographie, Cristal, 89, 18-22.

Catti, M., Ferraris, G., 1973. Hydrogen Bonding in the Crystalline State. Crystal Structure of $\mathrm{CaHAsO}_{4} \cdot 3 \mathrm{H}_{2} \mathrm{O}$ : Acta Crystallographica Section B: Structural Crystallography Crystal Chemestry, 29, 90.

Catti, M., Ferraris, G., 1974, Crystal Structure of $\mathrm{Ca}_{5}\left(\mathrm{HAsO}_{4}\right)_{2}\left(\mathrm{AsO}_{4}\right)_{2} \cdot 9 \mathrm{H}_{2} \mathrm{O}$ (Guerinite): Acta Crystallographica Section B: Structural Crystallography Crystal Chemestry, 30, 1789-1794.

Catti, M., Ivaldi, G., 1981. Mechanism of the reaction $\mathrm{Ca}_{5} \mathrm{H}_{2}\left(\mathrm{AsO}_{4}\right)_{4} \cdot 9 \mathrm{H}_{2} \mathrm{O}$ (ferrarisite) $->\mathrm{Ca}_{5} \mathrm{H}_{2}\left(\mathrm{AsO}_{4}\right)_{4} \cdot 5 \mathrm{H}_{2} \mathrm{O}$ ) (dimorph of vladimirite), and structure of the latter phase: Kristallografiya, 157, 119.

Catti, M., Ivaldi, G., 1983. On the topotactic dehydration $\mathrm{Ca}_{3}\left(\mathrm{AsO}_{4}\right)_{2}\left(\mathrm{H}_{2} \mathrm{O}\right)_{11}$ (phaunouxite)- $\mathrm{Ca}_{3}\left(\mathrm{AsO}_{4}\right)_{2}\left(\mathrm{H}_{2} \mathrm{O}\right)_{10}$ (rauenthalite), and the structure of both minerals: Acta Crystallographica Section B: Structural Science, 39, 4.

Chiari, G., Ferraris, G., 1971, The crystal structure of calcium dihydrogen arsenate $\mathrm{Ca}\left(\mathrm{H}_{2} \mathrm{AsO}_{4}\right)_{2}$ : Chemical communications, 105, 725-743.

Donahue, R., Hendry, M.J., 2003, Geochemistry of arsenic in uranium mine mill tailings, Saskatchewan, Canada. Applied: Geochemestry. $18,1733-1750$.

Dunn, P.J., Peacor, D.R., Sturman, B.D., 1980, Hauckite, $\mathrm{Fe}_{3}{ }^{3+}$ $(\mathrm{Mg}, \mathrm{Mn})_{24} \mathrm{Zn}_{18}\left(\mathrm{SO}_{4}\right)_{4}\left(\mathrm{CO}_{3}\right)_{2}(\mathrm{OH})_{81}$, a new mineral from Sterling Hill, New Jersey: American Mineralogist, 65, 192-195.

Ferraris, G., 1969, The Crystal Structure of Pharmacolite, $\mathrm{CaH}\left(\mathrm{AsO}_{4}\right) \cdot 2 \mathrm{H}_{2} \mathrm{O}$ ": Acta Crystallographica Section B: Structural Crystallography Crystal Chemestry, 25, 1544.

Ferraris, G., Chiari, G., 1970. The Crystal Structure of CaHAsO (Weilite). Acta Crystallographica Section B: Structural Crystallography Crystal Chemestry. 26, 403. 
Ferraris, G., Abbona, F., 1972, The crystal structure of $\mathrm{Ca}_{5}\left(\mathrm{HAsO}_{4}\right)_{2}\left(\mathrm{AsO}_{4}\right)_{2} \cdot 4 \mathrm{H}_{2} \mathrm{O}$ (Sainfeldite): Bulletin de la Société Francaise de Minéralogie et de Cristallographie, 95, 33.

Ferraris, G., Jones, D.W., 1972. A Neutron Diffraction Study of the Crystal Structure of Calcium Bis(dihydrogen arsenate), $\mathrm{Ca}\left(\mathrm{H}_{2} \mathrm{AsO}_{4}\right)_{2}$. Acta Crystallographica Section B: Structural Crystallography Crystal Chemestry 28, 2430.

Ferraris, G., Jones, D.W., Yerkess, J., 1971. Determination of hydrogen atom positions in the crystal structure of pharmacolite, $\mathrm{CaHAsO}_{4} \cdot 2 \mathrm{H}_{2} \mathrm{O}$, by neutron diffraction. Acta Crystallographica Section B: Structural Crystallography Crystal Chemestry, 27, 349.

Ferraris, G. Jones, D.W, Yerkess, J., 1972a. A Neutron and X-ray Refinement of the Crystal Structure of CaHAsO ${ }_{4} \cdot \mathrm{H}_{2} \mathrm{O}$ (Haidingerite). Acta Crystallographica Section B: Structural Crystallography Crystal Chemestry. 28, 209.

Ferraris, G., Franchini, A.M., Catti, M., 1972b. Crystal structure and hydrogen bonding in arsenates: $\mathrm{MgHAsO}_{4} \cdot 7 \mathrm{H}_{2} \mathrm{O}$ (rosslerite), $\mathrm{MgNH}_{4} \mathrm{AsO}_{4} \cdot 6 \mathrm{H}_{2} \mathrm{O}$ (As-struvite), $\mathrm{CaHAsO}_{4} \cdot 3 \mathrm{H}_{2} \mathrm{O}$ : Acta Crystallographica Section A, 28, S65b.

Hammersley, A., 1998, Fit2D V10.3 V4.0 (online), Grenoble, France, European Synchrotron Research Facility, published [January 2004], available at $<\mathrm{http}: / /$ www.esrf.eu/computing/scientific/FIT2D/>, consulted [June 2014 and November 2015], Paper ESRF98-HA01T, Reference Manual.

Herpin, P., 1963, La weilite, $\mathrm{CaH}\left(\mathrm{AsO}_{4}\right)$, Un nouvel arseniate de calcium isomorphe de la monetite: Bulletin de la Société Francaise de Minéralogie et de Cristallographie, 86, 368-372.

Jamieson, H.E., Walker, S.R., Andrade, C.F., Wrye, L.A., Rasmussen, P.E., Lanzirotti, A., Parsons, M.B., 2011. Identification and characterization of arsenic and metal compounds in contaminated soil, mine tailings, and house dust using shynchrotron-based microanalysis: Human and Ecological Risk Assesment 17, 12921309.

Julliot, F., Ildefonse, P., Morin, G., Calas, G., Kersabiec, A.M., Benedetti, M., 1999, Remobilization of arsenic from buried wastes at an industrial site: mineralogical and geochemical control: Applied Geochemestry, 14, 1031-1048.

Magalhaes, M.C., Williams, P.A., 2007. Apatite group minerals: Solubility and environmental remediation, in Letcher, T.M. (ed.), Thermodynamics, Solubility and Environmental Issues: The Netherlands, Elsevier, 327-340.

Magalhaes, M.C.F., 2002, Arsenic. An environmental problem limited by solubility: Pure and Applied Chemestry, 74, 1843-1850.

Mahapatra, P., Mahapatra, L., Mishra, B., 1986, Solubility of calcium hydrogen arsenate in aqueous medium: Indian Journal of Chemestry, Section, A25, 647-649.

Martínez-Villegas, N., Briones-Gallardo, R., Ramos-Leal, J.A., AvalosBorja, M., Castañón-Sandoval, A.D., Razo-Flores, E., Villalobos, M., 2013, Arsenic mobility controlled by solid calcium arsenates: A case study in Mexico showcasing a potentially widespread environmental problem: Environmental Pollution, 176, 114-122.
Myneni, S.C.B., Traina, S.J., Logan, T.J., Waychunas, G.A., 1997 Oxyanion Behavior in Alkaline Environments: Sorption and Desorption of Arsenate in Ettringite: Environmental Science \& Technology, 31, 1761-1768.

Nishimura, T., Robins, R.G., 1998. A re-evaluation of the solubility and stability regions of calcium arsenites and calcium arsenates in aqueous solution at $25{ }^{\circ} \mathrm{C}$. Mineral Processing and Extractive Metallurgy Review: An International Journal, 18, 283-308.

Nordstrom, D.K., Majzlan, J., Königsberger, E., 2014, Thermodynamic Properties for Arsenic Minerals and Aqueous Species: Review in Mineralogy and Geochmistry: 79, 217-255.

Onac, B.P., Hess, J.W., White, W.B., 2007, The relationship between the mineral composition of speleothems and mineralization of breccia pipes: Evidence from Corkscrew Cave, Arizona, Usa: The Canadian Mineralogist, 45, 1177-1188.

Ondrus, P., Veselovsky, F., Skala, R., Cisarova, I., Hlousek, J., Fryda, J., Vavrin, I., Cejka, Gabasova, A., 1997, New naturally occurring phases of secondary origin from Jáchymov: Journal of the Czsech Geological Society, 42, 4, 77-108.

Pantuzzo, F.L., Ciminelli, V.S.T., 2010, Arsenic association and stability in long-term disposed arsenic residues: Water Research, 44, 5631-5640.

Pierrot, R., 1964, Contribution to the mineralogy of natural calcium and calcium-magnesium arsenates: Bulletin de la Société Francaise de Minéralogie et de Cristallographie, 87, 169.

Robins, R.G., 1981, The solubility of metal arsenates. Metallurgical Transactions B, 12, 103-109.

Rodríguez-Blanco, J.D., Jimenez, A., Prieto, M., 2007, Oriented overgrowth of pharmacolite $\left(\mathrm{CaHAsO}_{4} \cdot 2 \mathrm{H}_{2} \mathrm{O}\right)$ on gypsum $\left(\mathrm{CaSO}_{4} \cdot 2 \mathrm{H}_{2} \mathrm{O}\right)$. Crystal Growth \& Design, 7, 2756-2763.

Swash, P.M., Monhemius, A.J., 1995. Synthesis, characterization and solubility testing of solids in the $\mathrm{Ca}-\mathrm{Fe}-\mathrm{AsO}_{4}$ system (abstract), in Sudbury '95-Mining and the Environment: Sudbury, Ontario Canada, CANMET, 17-28.

Walker, S.R., Parsons, M.B., Jamieson, H.E., Lanzirotti, A., 2009, Arsenic mineralogy of near surface tailings and soils: influences on arsenic mobility and bioaccesibility in the Nova Scotia gold mining districs: The Canadian Mineralogist, 47, 533-556.

Worzala, H., 1993. Zentrum fuer Anorganische Polymere.

Zhu, Y.N., Zhang, X.H., Xie, Q.L., Wang, D.Q., Cheng, G.W., 2006, Solubility and stability of calcium arsenates at $25^{\circ} \mathrm{C}$ : Water Air \& Soil Pollution, 169, 221-238.

Manuscript received: November 28, 2014

Corrected manuscript received: April 21, 2015

Manuscript accepted: May 5, 2015 